\section{JURNAL ABDIMAS

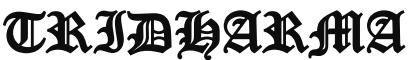

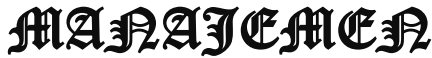

P-ISSN 2615-6849, E-ISSN 2622-3686

Jurnal ABDIMAS Vol. 2, No. 2, April 2021 Hal (12-18)

@Prodi Manajemen Fakultas Ekonomi Universitas Pamulang

Email: abdimasjurnal.unpam@gmail.com Telp: (021) 741-2566

\title{
MANAJEMEN KEUANGAN UNTUK MENGHADAPI DAN BERTAHAN DI ERA COVID 19
}

\author{
Veta Lidya Delimah Pasaribu, Helena Lia Yuniati, Rizky Pranata, Royke Sembayu, \\ Siti Marito Purba, Tia Tri Astuti Nurbayani \\ Dosen Dan Mahasiswa Prodi Manajemen Fakultas Ekonomi Universitas Pamulang \\ Email: veta01889@unpam.ac.id, Helena.subagya22@gmail.com, \\ pranatarizky68@gmail.com, roysembayu27@gmail.com, \\ sitimaritopurba522@gmail.com, tiatriastuti88@gmail.com
}

\begin{abstract}
Abstrak
Tujuan dari Pengabdian kepada Masyarakat (PKM) ini adalah untuk mengetahui cara memanej dan mempertahankan keuangan di era covid 19 yang dilaksanakan di PT. Abisatya Panca Nawa yang berada di Tangerang Selatan. Metode yang digunakan dalam PKM ini adalah dengan membandingkan cara-cara yang diambil untuk memenej keuangan dalam menghadapi dan bertahan di era covid 19. Hasil dari pelaksanaan PKM ini, diharapkan kita dapat lebih bijak dalam menggunakan keuangan perusahaan agar perusahaan dapat berjalan dengan stabil.
\end{abstract}

\section{Kata Kunci : Manajemen Keuangan, Pandemi Covid 19}

\begin{abstract}
The purpose of Community Service (PKM) is to see how to manage and maintain finances in the Covid 19 era carried out at PT. Abisatya Panca Nawa, located in South Tangerang. The method used in this PKM is by comparing the methods taken to manage finance in facing and surviving the Covid 19 era. The results of this PKM implementation, it is hoped that we can be wiser in using company finances so that it can run stably.
\end{abstract}

\section{Keywords: Financial Management, Covid Pandemic 19}

\section{PENDAHULUAN}

Dengan ditemukannya coronavirus 2 sindrom pernapasan akut yang parah (SARSCoV-2) pada akhir 2019 (Zhu et al., 2020) dan baru-baru ini dengan pandemi COVID-19 (CSSE, 2020), masyarakat dan ekonomi di seluruh dunia mengalami kejutan eksogen yang belum pernah terjadi sebelumnya (Sohrabi et al., 2020). Meskipun terjadinya pandemi yang disebabkan oleh virus baru tidak mengejutkan bagi ahli virus, langkahlangkah pengendalian infeksi seperti jarak sosial (Glass, Glass, Beyeler, \& Min, 2006) yang diambil untuk memperlambat penyebaran COVID-19 memberikan tekanan luar biasa pada sebagian besar ekonomi negara. Sebagian besar pelaku sentral dalam membentuk ekonomi akan mengakui pandemi saat ini sebagai peristiwa angsa hitam metaforis, yaitu, peristiwa mengejutkan yang tidak terduga yang sangat penting dan konsekuensi parah yang secara dramatis mengubah lingkungan politik dan ekonomi (Winston, 2020). Sementara peristiwa-peristiwa seperti itu dapat ditafsirkan sebagai peluang, penguncian yang belum pernah terjadi sebelumnya dari sebagian besar masyarakat yang timbul dari krisis COVID-19 menandai situasi saat ini sebagai krisis akut. SARS-CoV-2 memicu krisis dua kali lipat: 


\section{JURNAL ABDIMAS

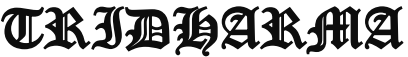

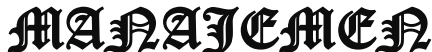

P-ISSN 2615-6849, E-ISSN 2622-3686

Jurnal ABDIMAS Vol. 2, No. 2, April 2021 Hal (12-18)

@ Prodi Manajemen Fakultas Ekonomi Universitas Pamulang

Email: abdimasjurnal.unpam@gmail.com Telp: (021) 741-2566
Pandemi COVID-19 telah menempatkan beban yang belum pernah terjadi sebelumnya pada banyak sistem kesehatan di seluruh dunia, dan langkah-langkah pengendalian infeksi telah menyebabkan krisis ekonomi dengan menghentikan aktivitas ekonomi dalam jumlah besar secara tiba-tiba.

Selain itu, sementara banyak krisis masa lalu lainnya telah menghantam umat manusia pada titik waktu tertentu dan secara regional (misalnya, badai seperti Katrina pada 2005) (Torn \& Hakim, 2009) atau berkembang dalam periode waktu yang lebih lama dengan efek global (misalnya, krisis keuangan 2008) (Feldkircher, 2014), COVID- 19 pandemi telah berkembang secara global dan tindakan penanggulangan yang diperlukan telah merusak ekonomi secara tiba-tiba.

Pada masa pandemi manajemen keuangan memegang peranan yang sangat penting. Manajemen yang diambil harus mampu beradaptasi dengan sangat cepat, dalam level organisasi/perusahaan. Tujuan penelitian ini adalah untuk mengetahui cara-cara memanajemen keuangan dengan baik dalam perusahaan yang saya cari dan kumpulkan dari beberapa artikel. Kami menghingpun dari beberapa artikel yang mengangkat topik manajemen keuangan di masa pandemi Covid-19. Pemetaan yang kami buat merupakan gambaran dari manajemen keuangan yang dapat dijadikan pedoman bagi perusahaan untuk memanej keuangan perusahaan agar perushaaan tetap berjalan dengan baik.

\section{Metode Penelitian}

Berikut adalah beberapa paparan artikel yang digunakan. Tabel pertama merupakan judul dari masing masing artikel. Selanjutnya dari artikel yang kami dapat, kami lakukan pendalaman terhadap isi.

\begin{tabular}{|l|l|l|l|}
\hline $\begin{array}{l}\mathrm{N} \\
\mathrm{O}\end{array}$ & Judul & Penulis & Tahun \\
\hline
\end{tabular}

\begin{tabular}{|c|c|c|c|}
\hline 1 & $\begin{array}{l}7 \text { tips } \\
\text { mengelol } \\
\text { a } \\
\text { keuangan } \\
\text { di masa } \\
\text { pandemi }\end{array}$ & $\begin{array}{l}\text { Virdita } \\
\text { Ratriani }\end{array}$ & $\begin{array}{l}\text { Jumat } \\
, \quad 16 \\
\text { Oktob } \\
\text { er } \\
2020\end{array}$ \\
\hline 2 & $\begin{array}{l}\text { Perlunya } \\
\text { Pengelola } \\
\text { an } \\
\text { Keuangan } \\
\text { di Masa } \\
\text { Pandemi }\end{array}$ & $\begin{array}{l}\text { Koran } \\
\text { Sindo }\end{array}$ & $\begin{array}{l}\text { Sabtu, } \\
10 \\
\text { Oktob } \\
\text { er } \\
2020\end{array}$ \\
\hline 3 & $\begin{array}{l}\text { Kiat-Kiat } \\
\text { Pengelola } \\
\text { an } \\
\text { Keuangan } \\
\text { Usaha } \\
\text { Selama } \\
\text { Pandemi }\end{array}$ & $\begin{array}{l}\text { Daniel } \\
\text { Nugraha }\end{array}$ & $\begin{array}{l}\text { Juli } \\
30, \\
2020\end{array}$ \\
\hline 4 & $\begin{array}{l}\text { Pentingny } \\
\text { a } \\
\text { Manajem } \\
\text { en } \\
\text { Keuangan } \\
\text { untuk } \\
\text { Jaga } \\
\text { Likuiditas } \\
\text { Perusahaa } \\
\text { n di Masa } \\
\text { Pandemi }\end{array}$ & $\begin{array}{l}\text { Reynas } \\
\text { Abdila }\end{array}$ & $\begin{array}{l}\text { Senin, } \\
31 \\
\text { Agust } \\
\text { us } \\
2020\end{array}$ \\
\hline 5 & $\begin{array}{l}\text { Manajem } \\
\text { en } \\
\text { Keuangan } \\
\text { U Kunci } \\
\text { UMKM } \\
\text { Bisa } \\
\text { Berkemb } \\
\text { ang di Era } \\
\text { Corona }\end{array}$ & $\begin{array}{l}\text { Taufik } \\
\text { Fajar, Jurna } \\
\text { lis }\end{array}$ & $\begin{array}{l}\text { Selasa } \\
13 \\
\text { Oktob } \\
\text { er } \\
2020\end{array}$ \\
\hline
\end{tabular}

Hasil dan Pembahasan

Berikut ini adalah penjabaran isi dari masing-masing artikel : 
JURNAL ABDIMAS

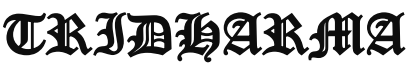

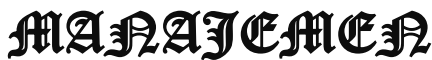

P-ISSN 2615-6849, E-ISSN 2622-3686

Jurnal ABDIMAS Vol. 2, No. 2, April 2021 Hal (12-18)

@ Prodi Manajemen Fakultas Ekonomi Universitas Pamulang

Email: abdimasjurnal.unpam@ gmail.com Telp: (021) 741-2566

\begin{tabular}{|c|c|c|}
\hline $\begin{array}{l}\mathrm{N} \\
\mathrm{o}\end{array}$ & Judul & Pokok Bahasan \\
\hline 1 & $\begin{array}{l}7 \text { tips } \\
\text { mengelola } \\
\text { keuangan } \\
\text { di masa } \\
\text { pandemi }\end{array}$ & $\begin{array}{l}\text { 1. Atur pengeluaran } \\
\text { tidak tetap dengan } \\
\text { metode rata-rata } \\
\text { Dalam pengaturan } \\
\text { arus kas (pemasukan } \\
\text { dan pengeluaran) } \\
\text { bulanan, maka } \\
\text { pengeluaran } \\
\text { dibedakan menjadi } \\
\text { dua jenis yaitu } \\
\text { pengeluaran tetap } \\
\text { dan variabel (tidak } \\
\text { tetap). } \\
\text { 2. Prioritaskan yang } \\
\text { wajib dan perlu } \\
\text { Prioritaskan } \\
\text { pengeluaran Anda } \\
\text { untuk kebutuhan } \\
\text { yang sifatnya wajib } \\
\text { dipenuhi } \\
\text { dibayar terlebih } \\
\text { dulu. } \\
\text { 3. Lunasi utang } \\
\text { konsumtif berbunga } \\
\text { besar, dan jangan } \\
\text { tambah lagi } \\
\text { Jika Anda memiliki } \\
\text { cadangan kas yang } \\
\text { cukup maka lunasi } \\
\text { utang jangka pendek } \\
\text { yang bersifat } \\
\text { konsumtif dan } \\
\text { berbunga besar, baik } \\
\text { yang ada di kartu } \\
\text { kredit, cicilan tanpa } \\
\text { kartu kredit, atau } \\
\text { pinjaman online. } \\
\text { 4. Simpan dana } \\
\text { darurat di tempat } \\
\text { yang semestinya } \\
\text { Dana darurat tentu } \\
\text { harus ada dan } \\
\text { tersedia di masa yang } \\
\text { penuh ketidakpastian } \\
\text { ini. } \\
\text { 5. Pikir dua kali } \\
\text { untuk cari untung } \\
\text { dari asuransi }\end{array}$ \\
\hline
\end{tabular}

\begin{tabular}{|c|c|c|}
\hline & & 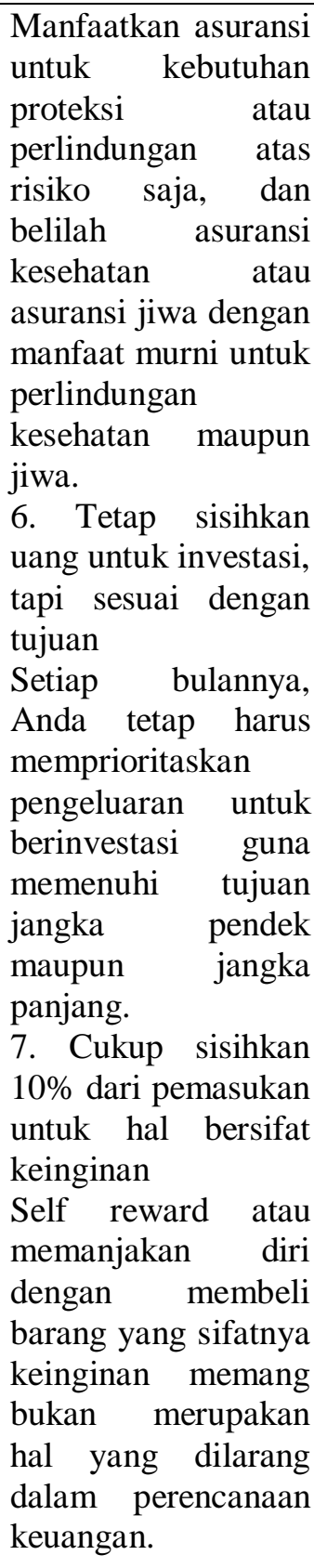 \\
\hline 2 & $\begin{array}{l}\text { Perlunya } \\
\text { Pengelolaa } \\
\text { n Keuangan } \\
\text { di Masa } \\
\text { Pandemi }\end{array}$ & $\begin{array}{l}\text { Pertama, pentingnya } \\
\text { dana darurat bagi } \\
\text { semua orang. Dana } \\
\text { ini wajib dimiliki dan } \\
\text { harus dialokasikan } \\
\text { secara terpisah. } \\
\text { Caranya dengan } \\
\text { menyisihkan dana } \\
\text { untuk kondisi yang } \\
\text { sangat darurat, } \\
\text { misalnya bila terjadi }\end{array}$ \\
\hline
\end{tabular}


JURNAL ABDIMAS

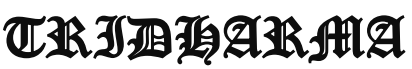

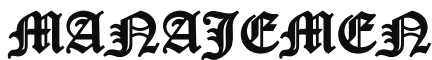

P-ISSN 2615-6849, E-ISSN 2622-3686

Jurnal ABDIMAS Vol. 2, No. 2, April 2021 Hal (12-18)

@ Prodi Manajemen Fakultas Ekonomi Universitas Pamulang

Email: abdimasjurnal.unpam@ gmail.com Telp: (021) 741-2566

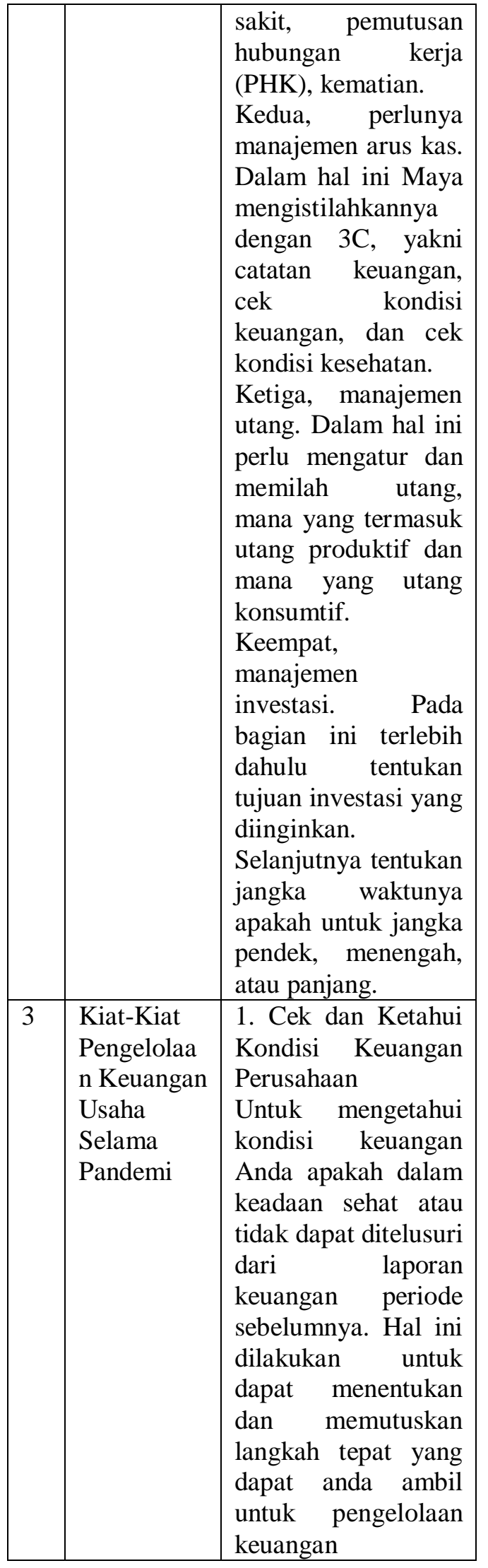

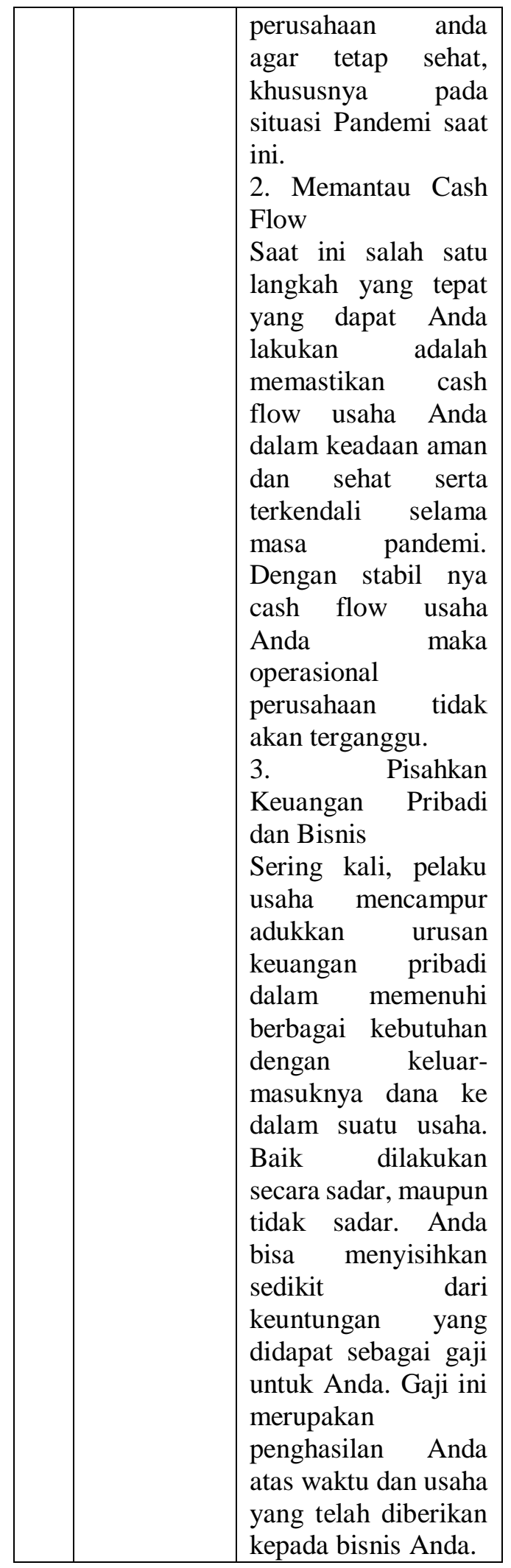


JURNAL ABDIMAS

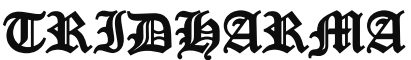

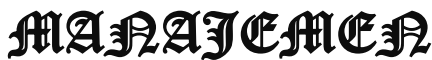

P-ISSN 2615-6849, E-ISSN 2622-3686

Jurnal ABDIMAS Vol. 2, No. 2, April 2021 Hal (12-18)

@ Prodi Manajemen Fakultas Ekonomi Universitas Pamulang

Email: abdimasjurnal.unpam@ gmail.com Telp: (021) 741-2566

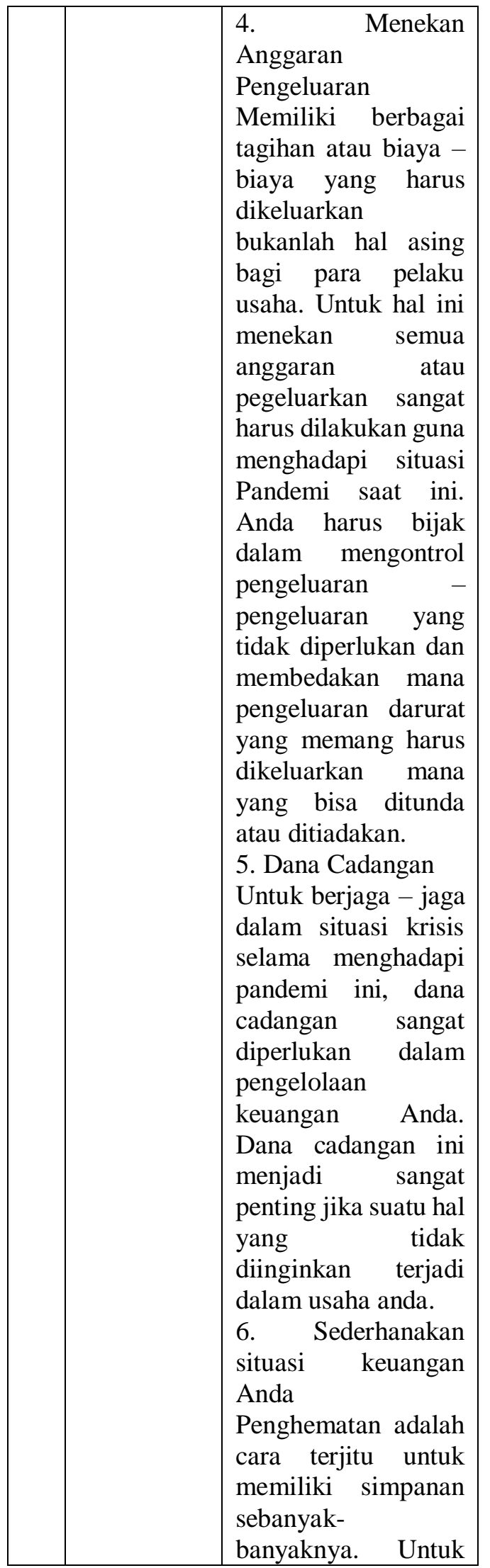

\begin{tabular}{|c|c|c|}
\hline & & 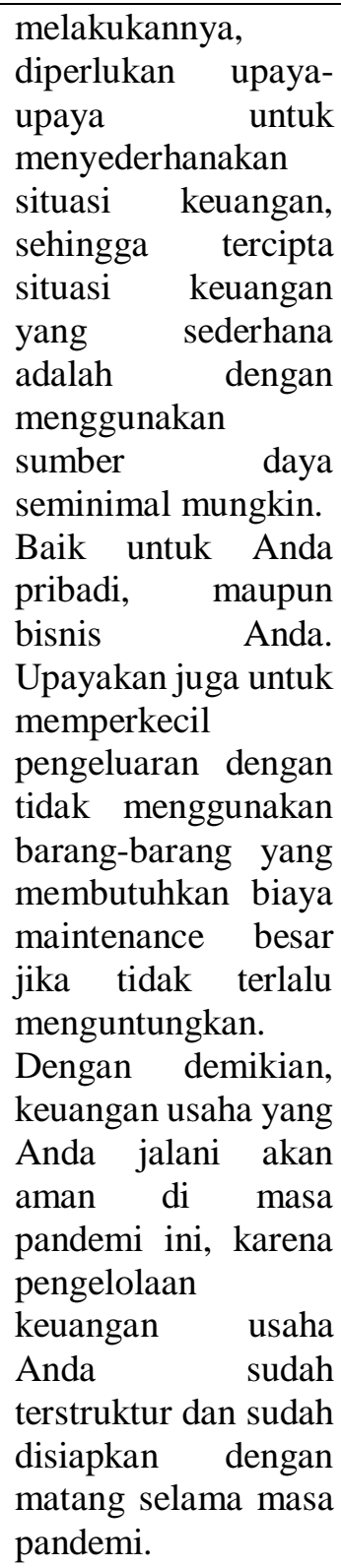 \\
\hline 4 & $\begin{array}{l}\text { Pentingnya } \\
\text { Manajemen } \\
\text { Keuangan } \\
\text { untuk Jaga } \\
\text { Likuiditas } \\
\text { Perusahaan } \\
\text { di Masa } \\
\text { Pandemi }\end{array}$ & $\begin{array}{lr}\text { Grant } & \text { Thornton } \\
\text { Indonesia } & \text { bersama } \\
\text { Bursa } & \text { Efek } \\
\text { Indonesia } & \text { (BEI) } \\
\text { melihat pentingnya } \\
\text { manajemen } \\
\text { keuangan/kas untuk } \\
\text { menjaga likuiditas } \\
\text { perusahaan selama } \\
\text { masa pandemi } \\
\text { Covid-19 ini. } \\
\text { Karena dengan } \\
\text { menjaga likuiditasny }\end{array}$ \\
\hline
\end{tabular}


JURNAL ABDIMAS

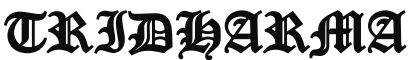

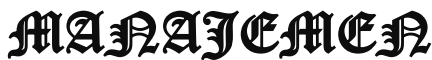

P-ISSN 2615-6849, E-ISSN 2622-3686

Jurnal ABDIMAS Vol. 2, No. 2, April 2021 Hal (12-18)

@ Prodi Manajemen Fakultas Ekonomi Universitas Pamulang

Email: abdimasjurnal.unpam@gmail.com Telp: (021) 741-2566

\begin{tabular}{|c|c|c|}
\hline & & $\begin{array}{lr}\text { a, perusahaan } \\
\text { mendapat } \\
\text { keuntungan dalam } \\
\text { memilih model } \\
\text { pendanaannya di } \\
\text { kemudian hari, salah } \\
\text { satunya adalah } \\
\text { dengan menerbitkan } \\
\text { obligasi atau dapat } \\
\text { juga melalui go } \\
\text { public } \\
\text { dicanangkan } \\
\text { Bursa oleh } \\
\text { Indonesia } \\
\text { (BEI). }\end{array}$ \\
\hline 5 & $\begin{array}{l}\text { Manajemen } \\
\text { Keuangan, } \\
\text { Kunci } \\
\text { UMKM } \\
\text { Bisa } \\
\text { Berkemban } \\
\text { g di Era } \\
\text { Corona }\end{array}$ & 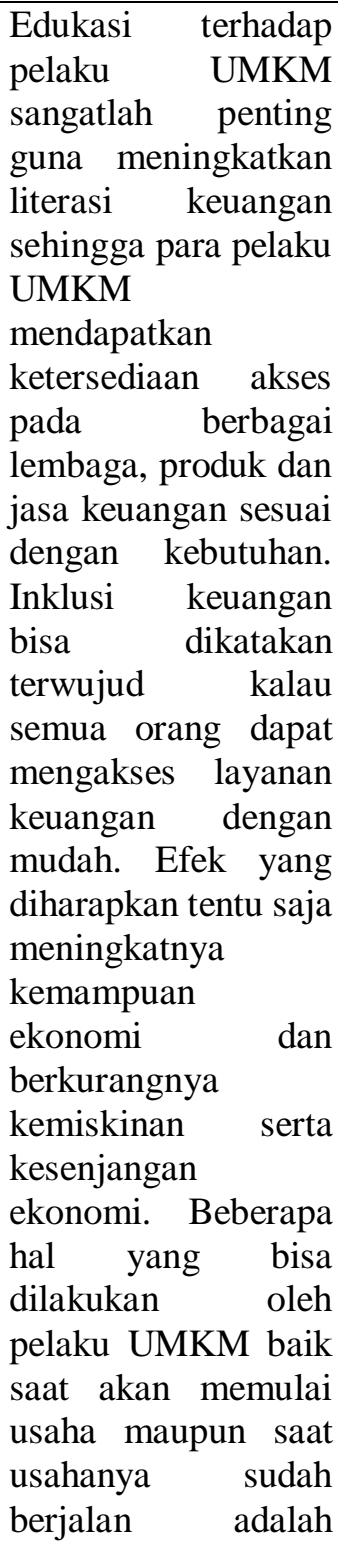 \\
\hline
\end{tabular}

\begin{tabular}{|l|l|}
\hline $\mid$\begin{tabular}{l|}
$\mid$ \\
untuk menekan biaya \\
operasional seefisien \\
mungkin dan \\
memisah rekening \\
pribadi dan rekening \\
usaha. Bila rekening \\
usaha sudah terpisah \\
maka arus bulanan \\
akan terlihat dengan \\
jelas.
\end{tabular} \\
\hline
\end{tabular}

\section{Kesimpulan}

Dengan munculnya wabah pandemi, maka cukup banyak strategi yang muncul dan digunakan dalam waktu yang sangat cepat. Adaptasi ini menjadi pembelajaran yang sangat berharga bagi orang-orang terlibat di dalam lingkungan organisasi. Secara umum tingkat kerugian pelaku bisnis meningkat, namun demikian tentu di bagian lain akan memunculkan keutungan yang sangat berarti, terutama pihak-pihak yang mampu beradaptasi sangat cepat. Di masa depan akan terjadi perubahan paradigma di segala bidang, oleh karena itu setiap organisasi harus selalu meninjau ulang manajemen keuangan mereka, dari artikel yang kita baca kita harus pintar dalam memanej keuangan perusahaan jangan sampai tercampur dengan uang pribadi. Dan harus pintar dalam menggunakan uang perusahaan mana yang memang harus digunakan dan mana yang tidak begitu penting karena kita tidak tau kapan pandemi ini akan berlangsung.

\section{Daftar Pustaka}

Iswandi dan Saiful Amiq, 2013, "Manajemen Keuangan Keluarga" Artikel Online https://juraganmakalah.blogspot.com/2 013/03/manajemen-keuangan-keluargai.html (Diakses Hari Selasa 6 Oktober 2020) 


\section{JURNAL ABDIMAS

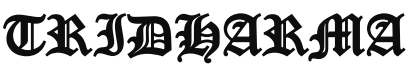

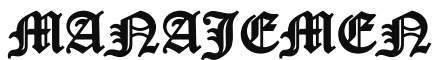

P-ISSN 2615-6849, E-ISSN 2622-3686

Jurnal ABDIMAS Vol. 2, No. 2, April 2021 Hal (12-18)

@Prodi Manajemen Fakultas Ekonomi Universitas Pamulang

Email: abdimasjurnal.unpam@gmail.com Telp: (021) 741-2566
Kasmir (2010), Pengantar Manajemen Keuangan. Edisi Kedua, Penerbit: Kencana Prenada Media Group, Jakarta.

Love Life Daily, 2020, "Manajemen Keuangan bagi Lajang dan Keluarga Baru di Era New Normal" Artikel Onlinehttps://ilovelife.co.id/blog/manaj emen-keuangan-bagi-lajang-dankeluarga-baru-di-era-new-normal/. (Diakses Hari Selasa 6 Oktober 2020).

Gitman, Lawrence, J.(2015). Principles of Manajerial Finance. International Edition, 10th edition, Pearson Education, Baston.

Hasibuan, Malayu S.P. (2012). Manajemen Sumber Daya Manusia. Jakarta : PT.Bumi Aksra.

Pasaribu, V. L. D., Susanti, F., \& Hartuti, E. T. K. (2019). Memotivasi Siswa dan Siswi SMK Letris Indonesia di Dalam Menentukan Pilihan Untuk Melanjutkan Pendidikan Atau Bekerja Setelah Lulus Sekolah. Jurnal Pengabdian Dharma Laksana, 1(2), 161-172.

Pasaribu, V. L. D., Agrasadya, A., Shabrina, N., \& Krisnaldy, K. (2020). MENJADI ENTERPRENEUR MUDA YANG MEMILIKI JIWA LEADERSHIP UNTUK MENGHADAPI MASA DEPAN. Abdi Laksana, 1(1).

Pasaribu, V. L. D., Elburdah, R. P., Sudarso, E., \& Fauziah, G. (2020). PENGGUNAAN MANAJEMEN WAKTU TERHADAP PENINGKATAN PRESTASI BELAJAR DI SMP ARAISIYAH. Jurnal ABDIMAS Tri Dharma Manajemen, 1(1).

Pasaribu, V. L. D., Sulaiman, S., Sutiman, S., Thaharudin, T., \& Purnomo, B. Y. (2020). PENGENALAN LETAK POSYANDU TERDEKAT DIKELURAHAN PISANGAN DENGAN MANAJEMEN PEMASARAN REVOLUSI 4.0 UNTUK MENINGKATKAN PENGETAHUAN MASYARAKAT LETAK DAN FUNGSI POSYANDU TERDEKAT PADA KELURAHAN PISANGAN. DEDIKASI PKM, 1(1), 105-110.
Pasaribu, V. L. D., Oktrima, B., Prabowo, B., Arianto, N., \& Haryoko, U. B. (2020). PROGAM PENDAMPINGAN DAN PENYELENGGARAAN PENDIDIKAN ANAK PADA USIA DINI TERHADAP PRESTASI BELAJAR DILINGKUNGAN RT 020 RW 009. KEL GIRI PENI. KEC WATES. YOGYAKARTA. JURNAL LOKABMAS KREATIF, 1(1), 71-75.

[1]http://https://personalfinance.kontan.co.i d/news/catat-ini-7-tips-mengelola-

keuangan-di-masa-pandemi/, diakses pada 10 Maret 2021

[2]https://ekbis.sindonews.com/read/19179 0/34/perlunya-pengelolaan-keuangan-dimasa-pandemi/, diakses pada 10 Maret 2021

[3]https://www.paper.id/blog/bisnis/pengel olaan-keuangan-selama-pandemi/, diakses pada 10 Maret 2021

[4]https://www.tribunnews.com/bisnis/202 0/08/31/pentingnya-manajemen-keuanganuntuk-jaga-likuiditas-perusahaan-di-masapandemi/, diakses pada 10 Maret 2021

[5]https://economy.okezone.com/read/202 0/10/13/455/2292941/manajemen-

keuangan-kunci-umkm-bisa-berkembangdi-era-corona/, diakses pada 10 Maret 2021

\section{FOTO DOKUMENTASI}

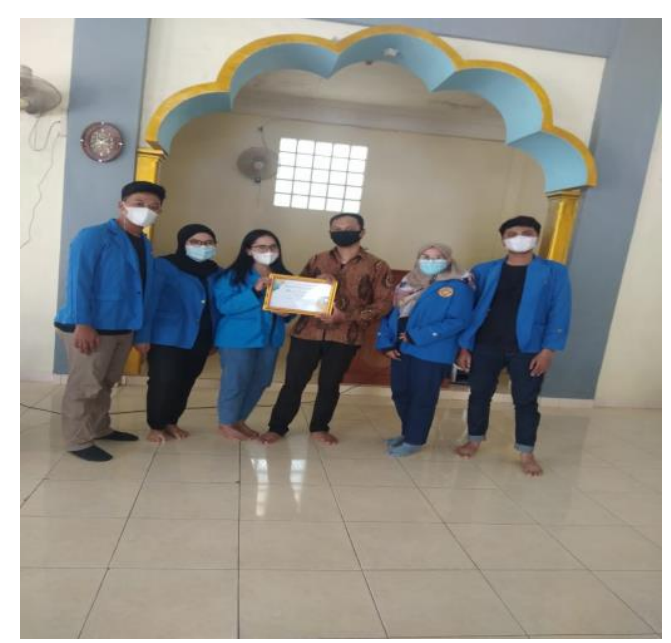

